Nat. Hazards Earth Syst. Sci. Discuss., https://doi.org/10.5194/nhess-2017-449

Manuscript under review for journal Nat. Hazards Earth Syst. Sci.

Discussion started: 12 February 2018

(c) Author(s) 2018. CC BY 4.0 License.

\title{
Earthquake safety analysis of masonry historical building case study: Historical Konya Gazi High School
}

\author{
M. Sami Donduren ${ }^{1}$, Seyit Uguz ${ }^{2}$ \\ ${ }^{1}$ Selcuk University, Faculty of Engineering,Departmen of civil Engineering, 42060, Konya, Turkey \\ ${ }^{2}$ Uludağ Üniversitesi, Departmen of Biyosystem Engineering, 06150, Bursa, Turkey \\ Correspondence to: M.Sami Donduren (sdonduren@hotmail.com)
}

\begin{abstract}
It is substantially significant to protect historical structures, which are an important part of our culture, against natural disasters such as earthquakes and to be transmitted to future generations. The structural behaviour of historical buildings must be well known to protect such structures. In order to be able to determine how safe the historic buildings are against the earthquake effect, it is necessary to determine the earthquake performance. Nowadays, the most commonly used method for the modelling and structural analysis of historical buildings systems with complex geometries is the finite element method.

In this study, Historical Konya Gazi High School was examined according to the present situation regarding the design and construction features with "Regulations on buildings to be built in earthquake regions" and structural analysis was performed in ETABS program. Graphs showing displacements, moments, shear forces and axial forces are used to interpret the results of the finite element analysis of the Historical Gazi High School. It has been informed about the stresses and damages that may be caused by any earthquake to this building, which has been serving the students for 97 years. It is aimed that this work will be a study to suggest a solution in terms of not losing the our historical values and delivering it to future generations.
\end{abstract}

Keywords: Earthquake, finite element methods, historical buildings

\section{Introduction}

Earthquakes cause damages and loss of lives in urban centres and cause significant losses in rural areas as well. Almost all of the buildings in the countryside, and also a large part of the old buildings in the city centre are masonry buildings. In addition, many of the historical buildings were built as masonry, wood and a mixture of them. There is no regulation that can be used in analysing the structural systems of such buildings. Today, because of the regulations used in the design of masonry buildings are prepared for new structures, it is substantially difficult to use these regulations in the study of historical structures.(Akgündüz, 2004).

Analysis of masonry buildings is rather exhausting compared to reinforced buildings (Aköz, 2008). Analysis made by package programmes for these kinds of buildings is in adequate. In recent years, through the use of computer technology, plastic analysis method which the nonlinear material properties and joints are taken into consideration has become more and more widely used from the classical analysis methods on the analysis of masonry structures (Anonim, 2016a). There are two types of approaches in the modelling of masonry structures; micro modelling and macro modelling. In the micro modelling, masonry units composed of bricks and mortar are modelled by separately (Anonim, 2016b). Therefore, in the micro modelling, the mechanical properties of the materials and binding materials of the structure need to be known exactly (Anonim, 2016c). Micro modelling, which usually involves a large computational load, is suitable for local analysis, but is not preferred for largescale analysis. (Dabanli, 2008). Applications in this model are done by using finite elements, discrete elements and limit analysis. In the macro model used for plastic analysis, the mechanical material properties of structure are defined by assuming as if the masonry structure materials are homogeneous (Çaktı et al., 2013). The finite element method is generally used in the structural analysis of masonry structures (Artar, M., 2006). Studies related to earthquake were conducted by other researchers such as those given (Jeen H. W., 2017, Stephanie L., 2017) in Refs. In this analytical method, the structure is modelled and analysed by separating it into finite elements in an appropriate number with regard to purpose of analysis. Package programs such as ETABS and SAP2000 are widely used for the structural analysis done by using finite element methods.

In this study, the earthquake safety of the historical Konya Gazi High School was investigated according to the present situation. This article provides information about the stresses and damages that may reveal due to any earthquake in this building which has been serving the students for 97 years. So that, this study will suggest about protection of our historical values and delivering them to future generations. Earthquake safety of the building was investigated by the ETABS programme which is one of the computer programmes used for nonlinear static analysis. The ETABS program is software of the CSI Company and is especially designed for 3D static analysis of buildings. Structural analysis is done by using finite element method in the program. (Uguz, 2016) 
Nat. Hazards Earth Syst. Sci. Discuss., https://doi.org/10.5194/nhess-2017-449

Manuscript under review for journal Nat. Hazards Earth Syst. Sci.

Discussion started: 12 February 2018

(c) Author(s) 2018. CC BY 4.0 License.

\subsection{Architectural features}

2. Material and methods

\subsection{Information about the building}

The architecture of Konya Gazi High School, which is the subject of this study, is Mimar Muzaffer. The construction of the building started in 1914 and was completed in 1917. The building, which was opened in 1917, was used as Military High School until 1923. It was used as "Dar'ül Muallim" between 1923-1934, "Konya Idadi" between 1934 and 1972 and Konya High School until 1972. The layout plan of Gazi High School is given in Figure 1.
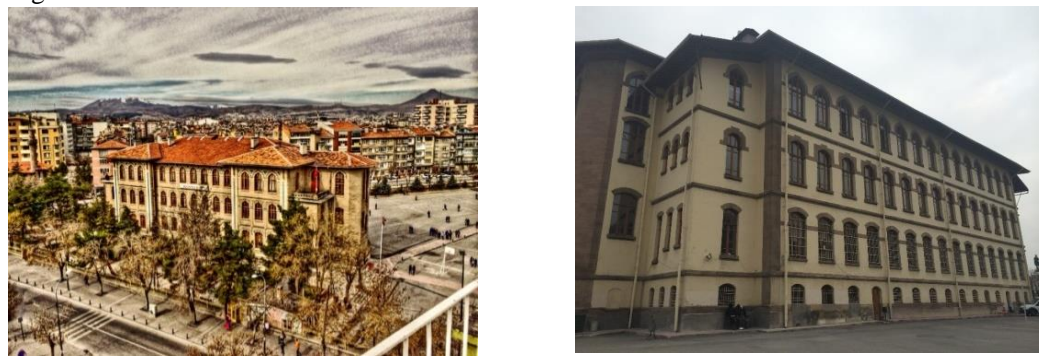

Figure 1. The layout plan of Gazi High School

The historical Gazi High School is located in Konya city center, at the intersection of Atatürk Street and Amber Reis Street. The building is positioned the south of the school area. There are other buildings for sports hall, laboratories and conference halls in the school garden. The empty space in the middle of these three buildings is used as a sports and ceremonial space. Because the building is a historical building, there is no architectural or static project of the building. For this reason, the architectural project of the building was made by taking the relievo. Konya Gazi high school has a basement floor, ground floor and two normal floors. The height of the floors differs from floor to floor. Basement and ground floor heights are 5,00 m, first floor and second heights are $4,50 \mathrm{~m}$

\subsection{Structural System and Material Properties}

The building is not exactly symmetric and also is built with masonry structural system. The form of the structural system varies with each floor. It was observed that rubble stone was used as material in the walls. It is thought that the rubble stones used in this structure are brought from the Sille region in Konya. When the walls of the structural system elements are examined, it is observed that the basement wall thickness is $90 \mathrm{~cm}$, the ground floor wall thickness is $80 \mathrm{~cm}$, the first floor wall thickness is $75 \mathrm{~cm}$ and the second floor wall thickness is $70 \mathrm{~cm}$. It is known that the second floor of the building was rebuilt with renovation, but it could not be verified because there were not enough resources. . The basement floor, the ground floor and the second floor slabs are not visible from the coatings. However, it has been observed that horizontal beams were used in the first story . Figure 2 shows the image of the first floor slab.

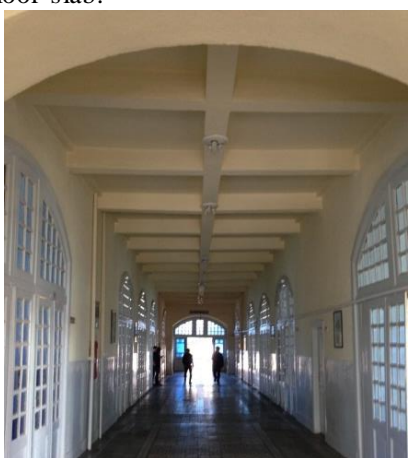

\section{Analysis programme}

Figure 2. Horizontal beams at the first floor

The ETABS program is one of the computer programs used for nonlinear static analysis. The program is software of CSI Company with ISO9001 quality certification and is specially designed for 3D static analysis of building type structures.

The CSI Company was founded in 1975 and is the manufacturer of programs, which are used in more than 160 countries worldwide. This program is also used in project designs of buildings such as Taipei Finance Centre in 
Nat. Hazards Earth Syst. Sci. Discuss., https://doi.org/10.5194/nhess-2017-449

Manuscript under review for journal Nat. Hazards Earth Syst. Sci.

Discussion started: 12 February 2018

(c) Author(s) 2018. CC BY 4.0 License.

Taiwan, One World Trade Centre in New York and Beijing National Stadium. ETABS program analyses by using the finite element method (Surlıbaş, 2013).

\subsection{Modelling and analysis in ETABS 2015 program}

\section{Structural Modelling}

In order to assessment the earthquake performance of the building, the Regulation on Buildings to be done in Earthquake Regions (DBYBHY, 2007) was followed. However, FEMA 356 (Prestandard and Commentary for Seismic Rehabilitation of Buildings) regulation is used in cases where our current earthquake regulations may be insufficient. First of all, axes were determined on the floor plans of the building while modelling was doing. Figure 3 shows the axes of the floor plan in the AutoCAD program.

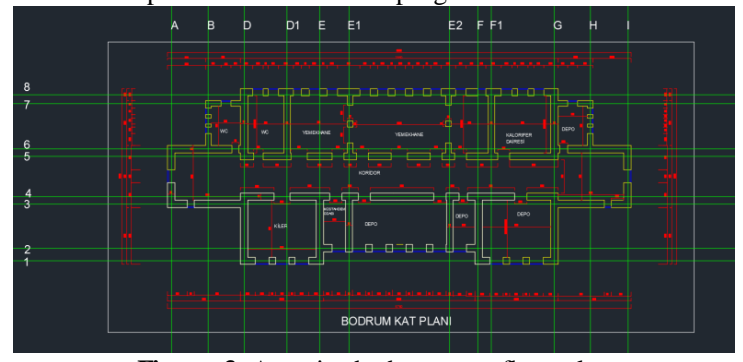

Figure 3. Axes in the basement floor plan

Afterwards axes were determined in the ETABS program and the elements coming from those axes were modelled. In literature, macro and micro finite element models can be shown as advanced modelling techniques of masonry structures. In the scope of this study, the structural analysis was carried out with the macro model of the finite element method created by ETABS 2015 software. The front and rear front of the building is shown in Figure 4.
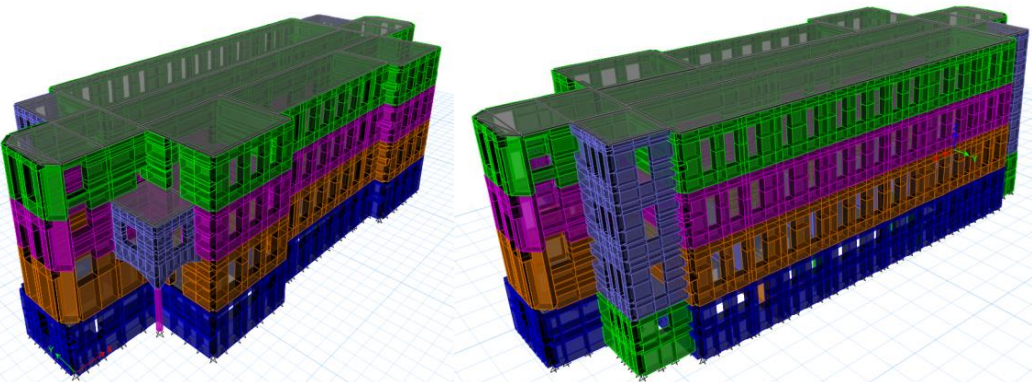

Figure 4. Front and rear front of the building

\section{The calculation of the Earthquake forces}

The parameters used in the calculation of earthquake forces are;

- Coefficient of Earthquake Zone $\left(\mathrm{A}_{0}\right)=0.1$ (IV. Region)

- Ground Class: Unpredicted $(\mathrm{S}(\mathrm{T})=2.5$ according to (DBYBHY-2007)

- Coefficient of Construction Importance (I) $=1.0$

- The conditions given in the seventh section of the earthquake regulations are considered on the determination of earthquake performance of existing or reinforced structures. According to the regulation, the coefficient of building importance is taken 1 in the new schoolbuildings projects.

- $\quad$ Coefficient of Structural System $(\mathrm{R})=2$

- Participation Coefficient of Live Load $(\mathrm{n})=0.6$ (School)

Equivalent Seismic Load was chosen as the method of earthquake analysis. Equivalent Seismic Load is defined as the user coefficient in ETABS. The loads are defined separately using positive and negative eccentricity for both $\mathrm{X}$ and $\mathrm{Y}$ directions.

$C=A_{0} \times I \times \frac{S(T)}{R}=0,125$

In the considered earthquake direction, the seismic mass (wi) to be used in calculating the earthquake loads of the building is given on DBYBHY 2007 as;

$\mathrm{w}_{\mathrm{i}}=\mathrm{g}_{\mathrm{i}}+\mathrm{nq}_{\mathrm{i}}$

Here, the live load participation coefficient is given in Table 1 . Since the building is a schoolbuilding, $\mathrm{n}$ is taken as 0.6. Accordingly, seismic mass will affect the structure is defined as $\mathrm{G}+0.6 \mathrm{Q}$ according to the regulation. 
Nat. Hazards Earth Syst. Sci. Discuss., https://doi.org/10.5194/nhess-2017-449

Manuscript under review for journal Nat. Hazards Earth Syst. Sci.

Discussion started: 12 February 2018

Table 1. Live load participation coefficient (DBYBHY, 2007)

\begin{tabular}{|l|c|}
\hline \multicolumn{1}{|c|}{ Binanın Kullanım Amacı } & $\boldsymbol{n}$ \\
\hline Warehouse, entree, etc. & 0,80 \\
\hline $\begin{array}{l}\text { School, student dormitory, sports facility, cinema, theater, concert hall, garage, } \\
\text { restaurants, shops, etc. }\end{array}$ & 0,60 \\
\hline Residential, office, hotel, hospital, etc. & 0,30 \\
\hline
\end{tabular}

3

4 Figure 5 shows the definition of the seismic mass defined as $\mathrm{G}+0.6 \mathrm{Q}$ according to the regulation in program.

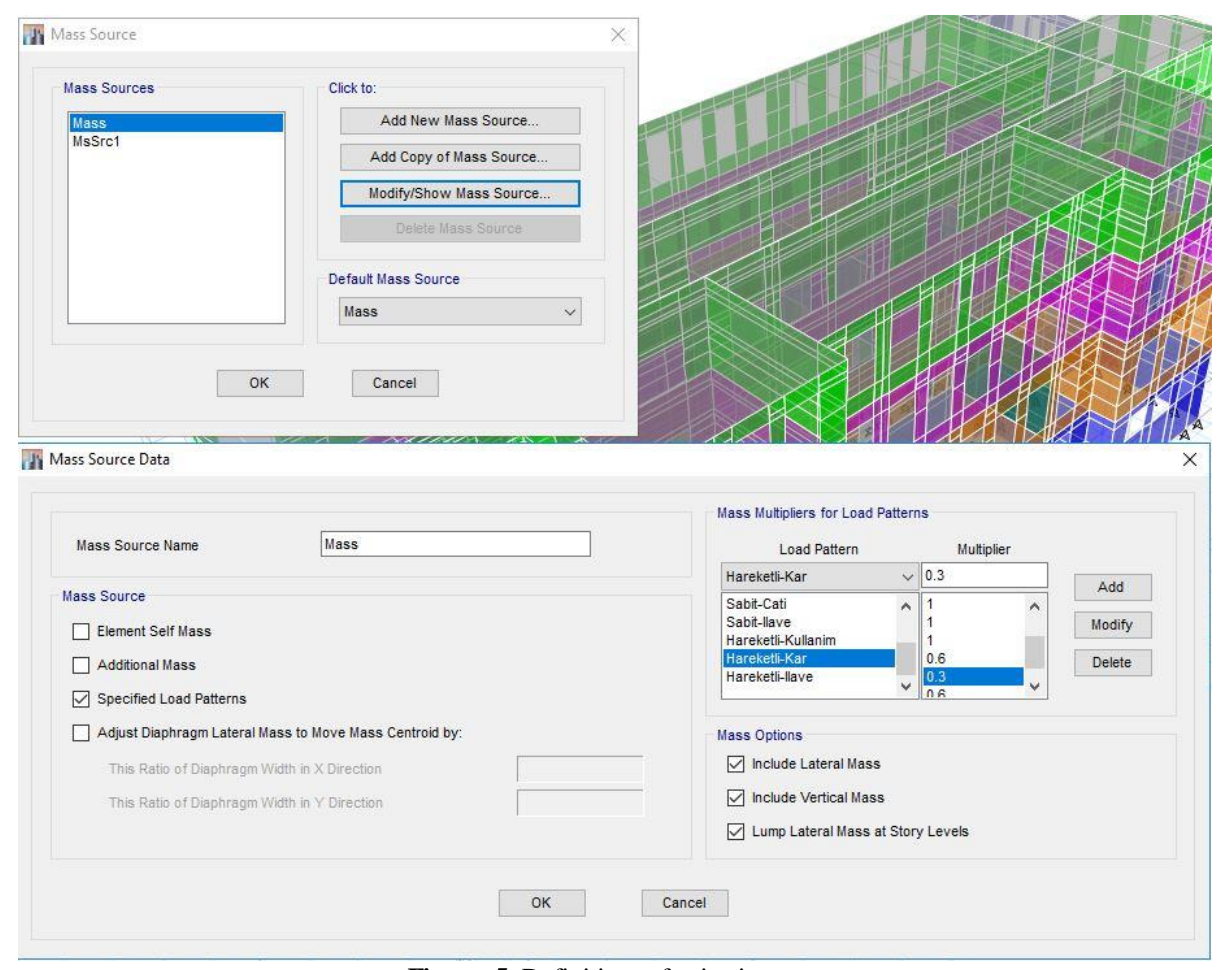

\section{Vertical Loads}

Figure 5. Definition of seis mic mass

The vertical loads affecting the building are shown in Table 2 as dead and live loads. Vertical loads were defined as linear load on horizontal beams and distributed load on the slabs. Hereby, the unit volume of the masonry walls in the building is taken as $1800 \mathrm{~kg} / \mathrm{m}^{3}$. For Floor, secondary wall and dead load of roof, the predicted load values were examined in place of the building were taken. Live and snow load are taken according to the values given in TS 498 .

Table 2. Equivalent earthquake load values

\begin{tabular}{|l|l|l|}
\hline \multicolumn{1}{|c|}{ Yükleme Adı } & \multicolumn{1}{c|}{ Yükleme Tipi } & \multicolumn{1}{c|}{ Değer } \\
\hline Hard-own & Own Weights of Structural Elements & $1800 \mathrm{~kg} / \mathrm{m}^{3}$ \\
\hline Hard-Coating & Floor Covering Loads & $100 \mathrm{~kg} / \mathrm{m}^{2}$ \\
\hline Fixed-Tali Wall & Non-Carrier Wall Loads & $300 \mathrm{~kg} / \mathrm{m}^{2}$ \\
\hline Fixed-Roof & Roof Fixed Load & $200 \mathrm{~kg} / \mathrm{m}^{2}$ \\
\hline Moving-Control & TS 498 Moving Load & $350 \mathrm{~kg} / \mathrm{m}^{2} \mathrm{ve} 500 \mathrm{~kg} / \mathrm{m}^{2}$ \\
\hline Moving-Snow & TS 498 Konya Region Snow Load & $100 / \mathrm{m}^{2}$ \\
\hline
\end{tabular}


Nat. Hazards Earth Syst. Sci. Discuss., https://doi.org/10.5194/nhess-2017-449

Manuscript under review for journal Nat. Hazards Earth Syst. Sci.

Discussion started: 12 February 2018

(c) Author(s) 2018. CC BY 4.0 License.

The load combinations used for stress control of the beam walls are derived in accordance with the DBYBHY and TS 500 standards.

\section{Definition of Materials and structural sections}

The walls of the building are constructed with shell elements that allow the formation of finite elements. Critical points are divided into shell elements for creating finite elements (Mesh). Meshes for each element in critical points are by the program itself. Figure 6 shows the definition of a wall of $80 \mathrm{~cm}$ thickness on the ground floor of the building.

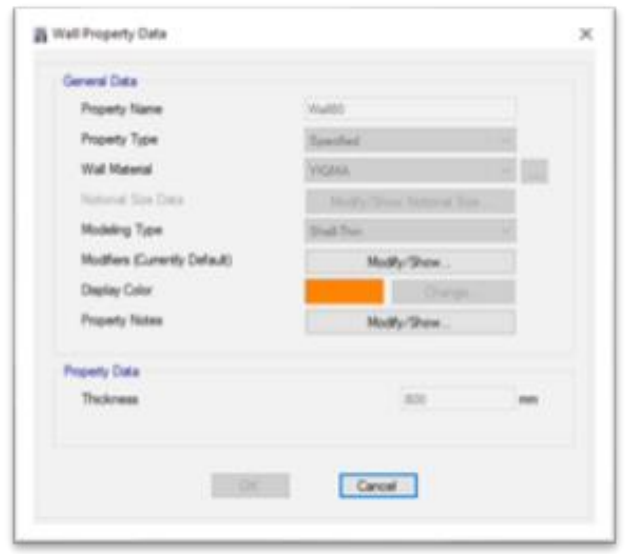

Figure 6. Typical definition of a $80 \mathrm{~cm}$ thickness wall on the ground floor

Floor slabs are also modelled with shell elements to create a diaphragm effect. Figure 7 shows the names of the internal forces of the shell elements. It is also shown the stress of the plane shell elements. In addition, plane shell elements show to stresses. In any element of the model, stress values at any angle can be converted to principle stresses. The maximum shear stresses are calculated as shown in Figure 7.

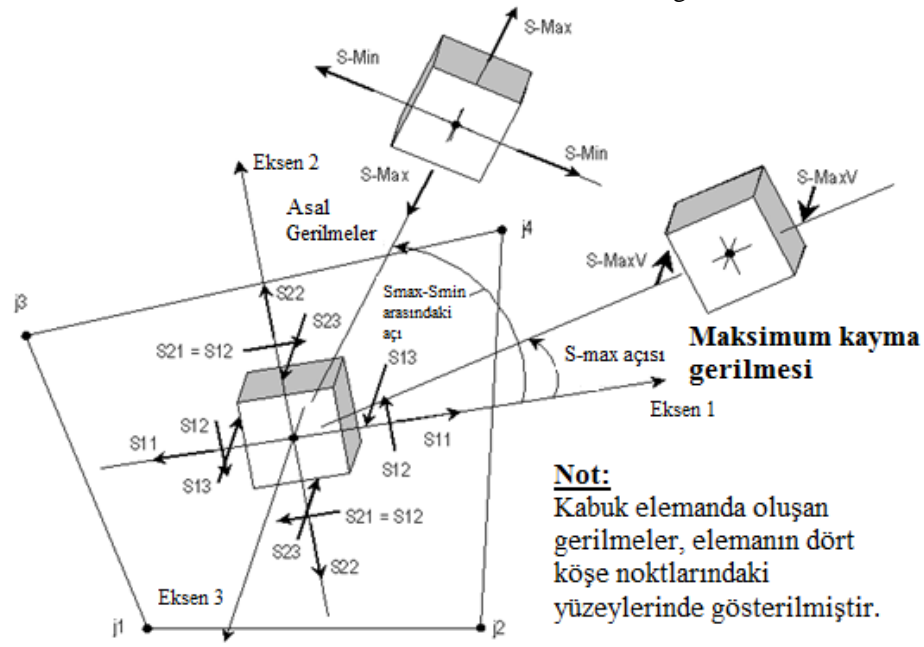

Figure 7. Principal axes and stress directions of shell elements (Dabanl, 2008)

In describing the masonry wall material of the masonry, the Elasticity Module of the masonry units used in the construction of the masonry according to the regulations is given as Ed $=200 \mathrm{fd}$, which is 200 times the character pressure resistance of the material. However, in the 2016 Earthquake Draft Regulation, the modulus of elasticity modulus of the masonry wall (if not tested) is 750 times the characteristic compressive strength. According to the literature, since the value of $200 \mathrm{fd}$ is seen as a small value, the elasticity module is taken as 750 times of the character pressure resistance.

According to this; 
Nat. Hazards Earth Syst. Sci. Discuss., https://doi.org/10.5194/nhess-2017-449

Manuscript under review for journal Nat. Hazards Earth Syst. Sci.

Discussion started: 12 February 2018

(c) Author(s) 2018. CC BY 4.0 License.

Natural Hazards

and Earth System

Sciences

Discussions

3 The wall shift module is limited to $40 \%$ of the elasticity module. Hereunder;

$$
\mathrm{G}_{\text {duvar }}=\frac{E}{2 \times(1+\gamma)}=\frac{900}{2 \times(1+0,25)}=360 \mathrm{Mpa}
$$

In this equation, $\mathrm{E}$ is the modulus of elasticity, and $\gamma$ is the poisson ratio and is taken as 0.25 . The values obtained in the framework of these rules are listed below.

- $\quad \mathrm{fk}=1,2 \mathrm{MPa}$ (Characteristic Pressure Resistance-DBYBHY 2007)

- $\mathrm{E}_{\mathrm{wall}}=900 \mathrm{MPa}$ (Elasticity Module)

- $\mathrm{G}_{\mathrm{wall}}=360 \mathrm{MPa}$ (Shear Module)

In the determination of material properties, first the items of DBYBHY 2007 were followed. However, the modulus of elasticity of the DBYBHY is very low because it defines the modulus of elasticity as $200 * \mathrm{fd}$. In this case, it has been found that the structural system resistance falls and accordingly there is a decrease in internal forces (stresses). Figure 8 shows the menu showing material properties in ETABS program.

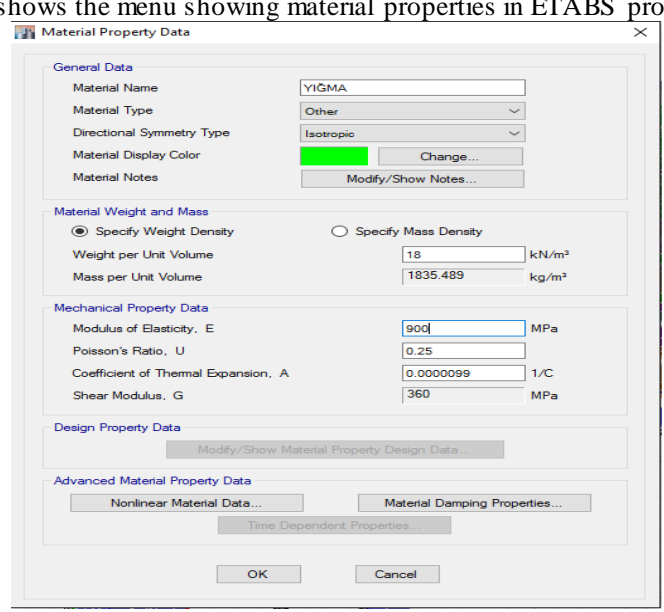

\section{Results}

Figure 8. Material properties

\subsection{Modal analysis results}

Modal analysis, known as eigen-value analysis, is an analysis used to determine free vibration periods and mode shapes of a structure. Free vibration periods and modes can be determined by using the mass and stiffness matrices of the building system. Modal analysis was performed with the Etabs program of the finite element model of the historical Konya Gazi High School. Modal analysis was performed in 12 modes with Eigen Vectors. Vibration in modal form pertaining to a free vibration period implies how much of the total mass of the structure influences and incorporates into the resonance motion by the mass participation rate. In the earthquake regulation, a lower limit is given for the sum of modal masses.

According to the regulation, it is stated that the number of sufficient vibration modes in each of the $\mathrm{x}$ and $\mathrm{y}$ earthquake directions, will be determined according to the rule that the sum of the active calculated masses for each mode is never less than $90 \%$ of the total building mass. However, if fewer modes are used in the analysis of historical buildings, it is very difficult to catch this limit. As a result of the analysis, the first mode of the building is 0.50 second (the vibration period is in the " $\mathrm{Y}$ " direction), the second mode is 0.404 second in buckling, and third mode is 0.314 second in the direction of " $\mathrm{X}$ ". The modal analysis parameters and result mass distributions of the modal analysis in the $\mathrm{X}$ and $\mathrm{Y}$ directions are given in Table 3. Accordingly, we see that the mass of the structure in the Y direction exceeds $70 \%$ in the first mode and is a displacement in the Y direction. Similarly, when we look at the mass participation in the $\mathrm{X}$ direction, we see that $70 \%$ mass participation in the third mode and a displacement in the $\mathrm{X}$ direction is seen (Figure 12). Again, when we look at the mass participation in the second mode, there is no mass participation in either way. As shown in Figure 9, there is no displacement in the $\mathrm{X}$ and $\mathrm{Y}$ directions, but buckling occurs in the structure. 
Nat. Hazards Earth Syst. Sci. Discuss., https://doi.org/10.5194/nhess-2017-449

Manuscript under review for journal Nat. Hazards Earth Syst. Sci.

Discussion started: 12 February 2018

(c) Author(s) 2018. CC BY 4.0 License.
Natural Hazards 웅 and Earth System Sciences

Discussions

(c) $\underset{\mathrm{By}}{(i)}$

$\frac{1}{2}$

3

4

Table 3. X-Y mass participation of modal analysis

\begin{tabular}{|c|c|c|c|}
\hline $\begin{array}{c}\text { Mode } \\
\text { Numbers }\end{array}$ & Period (sn) & $\begin{array}{c}\text { Mass Participation in } \\
\text { X direction }\end{array}$ & $\begin{array}{c}\text { Mass Participation in } \\
\text { Y direction }\end{array}$ \\
\hline 1 & 0.501 & 0.000 & 0.725 \\
\hline 2 & 0.404 & 0.001 & 0.000 \\
\hline 3 & 0.314 & 0.769 & 0.000 \\
\hline
\end{tabular}

5

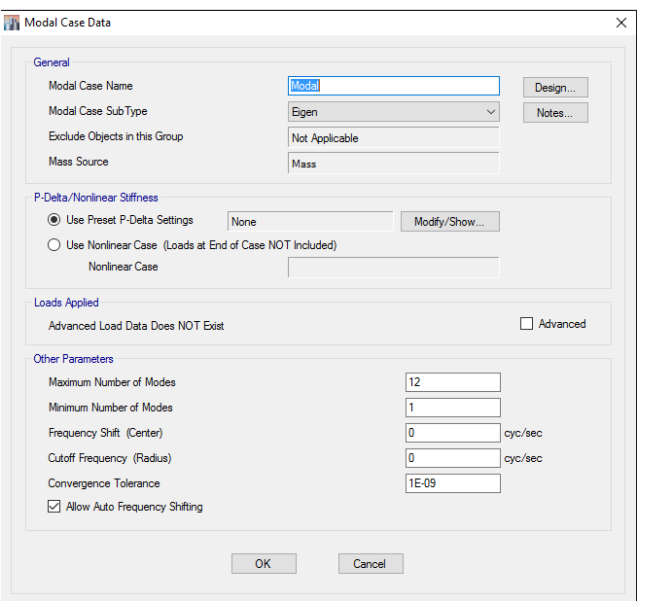

Figure 9. Modal Analysis Parameters

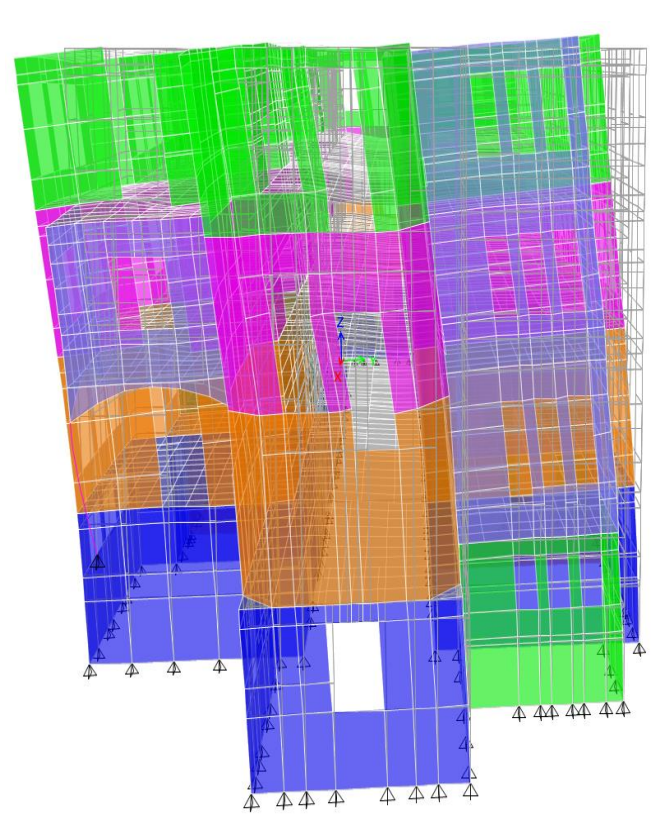

6

Figure 10. First mode ( $\mathrm{Y}$ direction) 
Nat. Hazards Earth Syst. Sci. Discuss., https://doi.org/10.5194/nhess-2017-449

Manuscript under review for journal Nat. Hazards Earth Syst. Sci.

Discussion started: 12 February 2018

(c) Author(s) 2018. CC BY 4.0 License.
Natural Hazards and Earth System Sciences

Discussions $\frac{1}{2}$

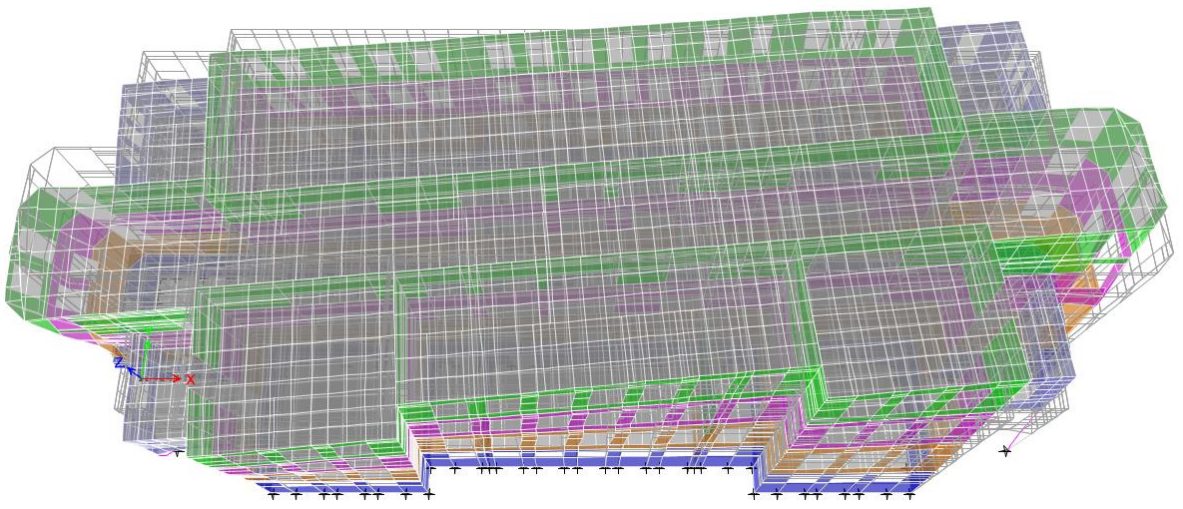

Figure 11. Second mode (Buckling)

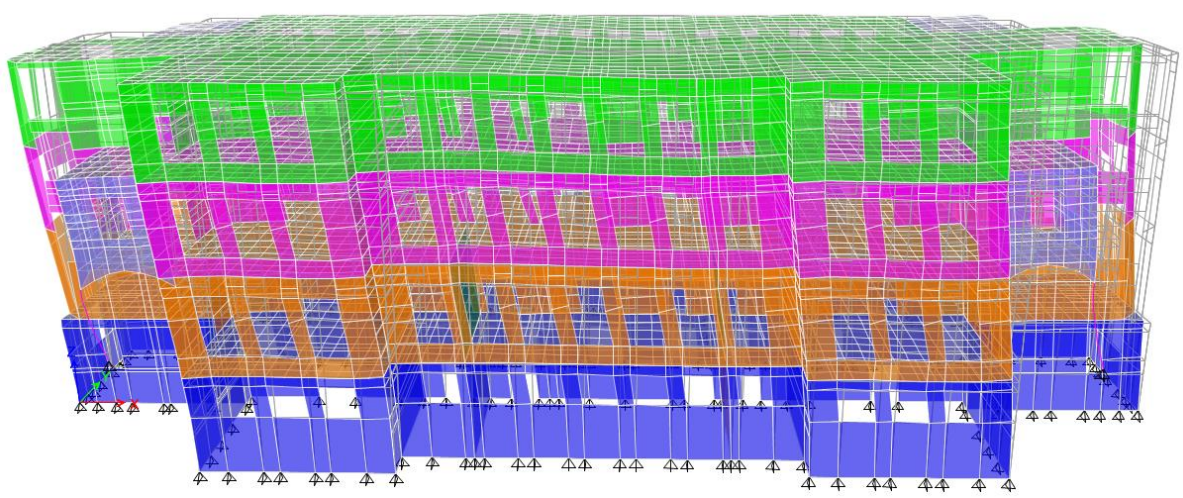

Figure 12. Third mode (X direction)

\subsection{Axial stress results}

Axial stresses are occurred the result of combination of vertical (static and moving) loads acting on the building and tensile and compressive loads occurring during the earthquake. As it can be seen in Figure 13, the Axial Axis (Z Direction) in the ETABS software is shown in green. Thus, axial stress controls were carried out for the "S22" stresses named in the ETABS program. Figure 14 shows the local axes of the model.

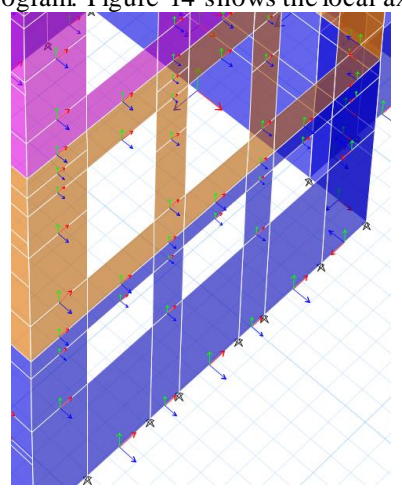

Figure 13. Local axles 
Nat. Hazards Earth Syst. Sci. Discuss., https://doi.org/10.5194/nhess-2017-449

Manuscript under review for journal Nat. Hazards Earth Syst. Sci.

Discussion started: 12 February 2018

(c) Author(s) 2018. CC BY 4.0 License.

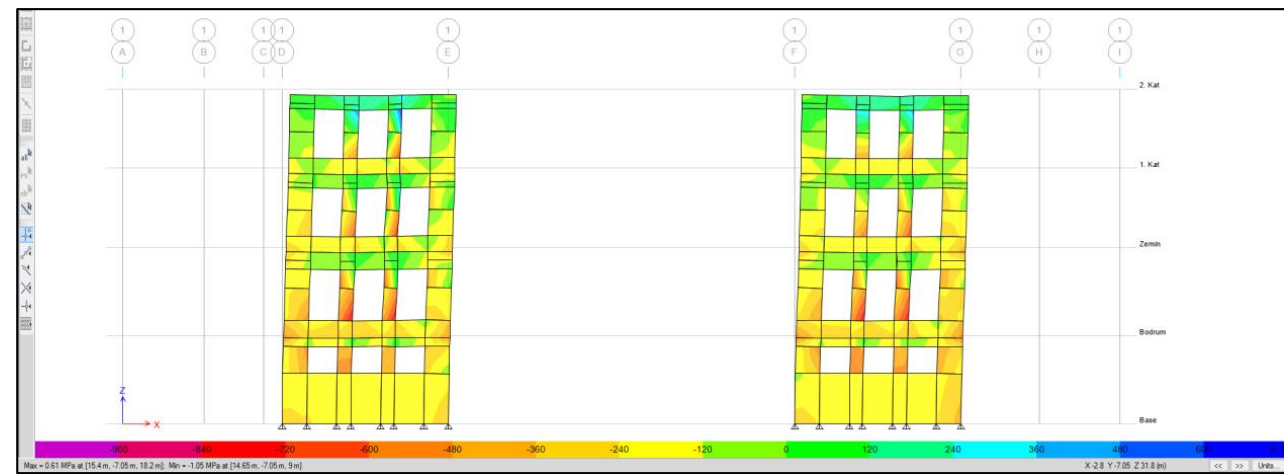

Figure 14. Axial stresses for 1-1 axis

3 Compressive stresses occurring in walls need to be compared with permissible stresses according to the type of 4 masonry wall. In this calculation, the loads from the walls and floors will be taken into consideration. These stresses cannot be greater than the value of permissible value when ruled according to wall type (DBYBHY, 2007). Permissible wall pressure strengths are taken from the wall safety stress table given in the regulations, depending on the class of mortar used in the wall and the average unconfined compressive strength of the wall material. Stone was used as wall material in Konya Gazi High School. The pressure resistance of the material used in the wall could not be determined when the wall part strength test was not carried out in the study. Therefore, the pressure safety stress $(0.3 \mathrm{MPa})$ given for the stone wall material in the regulation is used. The maximum pressure stress values specified in DBYBHY-2007 are not exceeded throughout the system. However, as it can be observed from the forms presented above, the axial stresses in the local regions (especially around the voids) are found to be in the order of 0.6 to 0.8 to $1.0 \mathrm{MPa}$.

4.3. Shear stress results

The shear stresses acting on the building are caused by the horizontal loads caused by the earthqu ake effect. In accordance with the above figures and local axes, shear stresses were followed by "S11" values. According to DBYBHY-2007, Safe shear stress is calculated according to the following equation;

$$
\tau_{e m}=\tau_{0}+\mu \sigma
$$

Where; $\sigma$ is the axial stress due to the vertical loads, and $\mu$ is the friction coefficient. In our earthquake regulations, it is clear that the coefficient of friction can be taken as 0.5 in head 5.3.3.4. In the calculation of vertical tension, $\mathrm{G}+0.6 \mathrm{Q}$ was taken into account in accordance with earthquake mass.

Average axial stress due to vertical load $=0.13 \mathrm{MPa}$

Found as; $\tau_{e m}=0,1+0,5 \times 0,13=0,165 \mathrm{Mpa}$

As can be seen from the figures given above, it is seen that the shear stresses in the local regions (especially around the spaces) reach to $0.3 \mathrm{MPa}$. However, it is seen that the maximum shear stress $(0.165 \mathrm{MPa})$ calculated by the formula in DBYBHY is not exceeded throughout the system.

4.4. Relocation results

Since DBYBHY 2007 did not observe the displacement criterion for masonry structures, displacement controls were carried out in accordance with FEMA 356 regulation. In FEMA 356, performance targets, performance levels and ranges of structural and non-structural elements, earthquake impact levels are defined. In this regulation, explanations are made about the modelling of masonry structures. FEMA 273/356 standards are used in addition to DBYBHY 2007 in evaluating existing structures in our country. Figures (15-18) show the maximu $\mathrm{m}$ displacements in the $\mathrm{X}$ and $\mathrm{Y}$ directions of the model. 
Nat. Hazards Earth Syst. Sci. Discuss., https://doi.org/10.5194/nhess-2017-449

Manuscript under review for journal Nat. Hazards Earth Syst. Sci.

Discussion started: 12 February 2018

(c) Author(s) 2018. CC BY 4.0 License.

(c) (i)

\section{Natural Hazards and Earth System Sciences \\ Discussions}

$\frac{1}{2}$

3
4

5

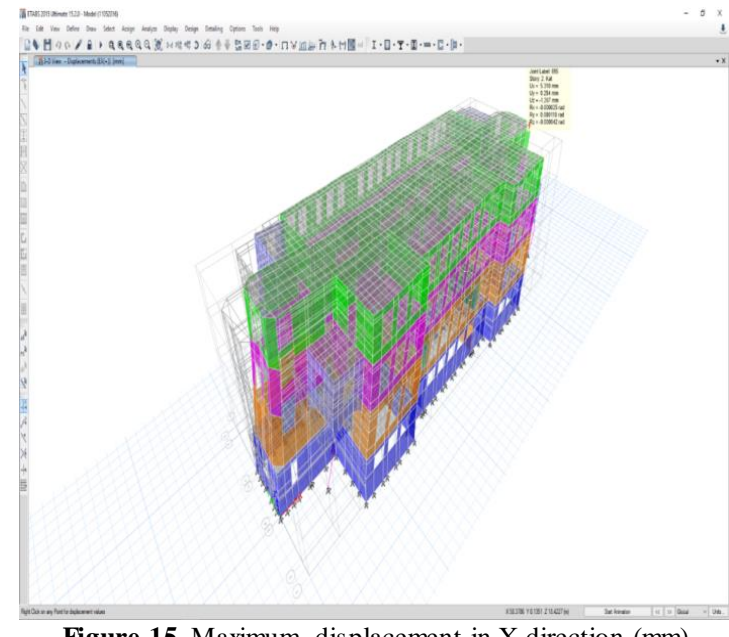

Figure 15. Maximum displacement in X direction (mm)

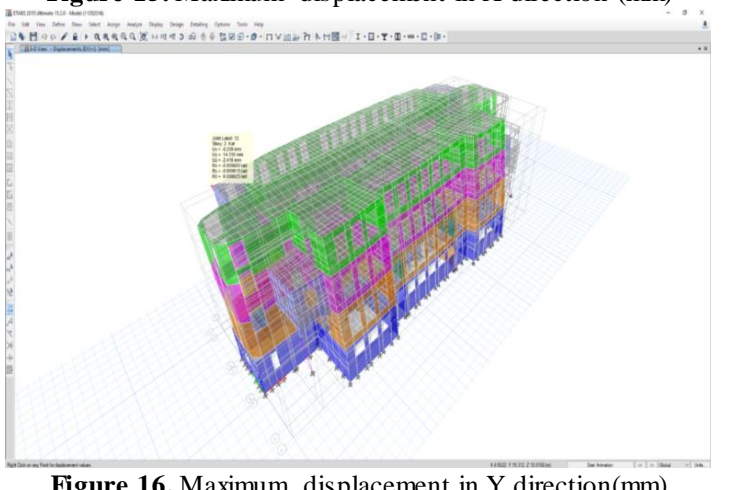

Figure 16. Maximum displacement in $\mathrm{Y}$ direction(mm)

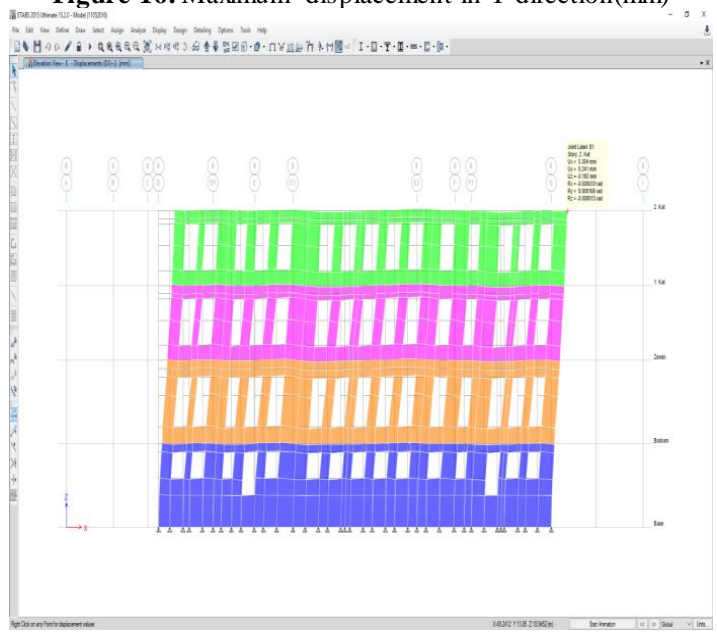

Figure 17. Maximum displacement in $8-8$ axis (mm) 
Nat. Hazards Earth Syst. Sci. Discuss., https://doi.org/10.5194/nhess-2017-449

Manuscript under review for journal Nat. Hazards Earth Syst. Sci.

Discussion started: 12 February 2018

(c) Author(s) 2018. CC BY 4.0 License.

Natural Hazards

and Earth System Sciences

Discussions

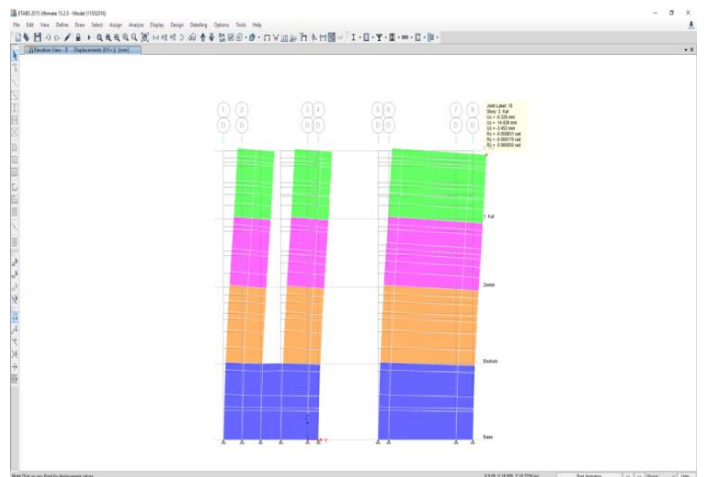

Figure 18. Maximum displacement in D-D Axis (mm)

As can be seen from the figures shown above, the maximum displacement is $15 \mathrm{~mm}$ in the $\mathrm{Y}$ direction. Since $\mathrm{R}$ $=2$ is used in this analysis, the elastic displacement must be calculated as $15 \mathrm{~mm} \times 2=30 \mathrm{~mm}$. In this case, maximu $m$ relative displacement is;

$$
\delta_{i \max }=30 \mathrm{~mm}<19 \mathrm{~mm} \times 0,004=76 \mathrm{~mm}
$$

$0.4 \%$ specified in this formula is taken from FEMA 356 regulation.

\section{Acknowledge}

This study was produced from the graduate thesis Seyit Uguz, which was completed in consultation with M. Sami Döndüren.

\section{Discussion}

In this study, performance analysis and static analys is of historical Konya Gazi High School building constructed as masonry structure and was investigated. As a result of the analyses made, it has been determined that the most forced parts of the building in the static condition are the edges of the window and door openings. The bearing wall lengths, floor heights, void ratios in the building do not provide the regulation requirements when the present state of the structure is examined according to the requirements of today's regulations. Moreover, it is seen that the most difficult parts of the construction are window and door edges according the results of analysis of ETABS. Thin and deep cracks on the edges of the doors and windows were also observed in the buildings it is recommended to repair of cracks in these areas.

The detailed results of analyses carried out in order to determine the performance of the building under the effects of earthquake loads are presented in the above sections. The summaries of the results obtained are indicated below.

- The lateral displacement of the structural system is $30 \mathrm{~mm} / 19000 \mathrm{~mm}=0.16 \%$ and provides the criteria of FEMA 356 regulation.

- The axial pressure stresses in the structural system are lower than 0.3 MPa on average.

- Although the axial stresses reach 1.0 MPa in local areas, they are below the characteristic compressive strength (1.2 MPa).

- The shear stresses in the structural system are less than $0.15 \mathrm{MPa}$ on average. Although the shear stresses reach $0.3 \mathrm{MPa}$ in the local regions, they are below the shear stress $(0.7 \mathrm{MPa})$ calculated according to the characteris tic compressive strength.

- It is thought that some of the cracks seen in the building may originate in the settlement of the building. Therefore, it is considered appropriate to take precautions related to the foundation of the building.

- And also, it will be useful for the next lifetime of the building if the cracks observed in the building are repaired according to the strengthening methods.

- Since the back wall of building is painted with complex plaster, and ruins the historical texture of building, It is suggested that such applications should not be repeated.

It is thought that the analyses made in the scope of the study and the results obtained are very important for carrying out similar studies in future works related to such subjects and also for the his torical structures having different carrier system characteristics in our country. 
Nat. Hazards Earth Syst. Sci. Discuss., https://doi.org/10.5194/nhess-2017-449

Manuscript under review for journal Nat. Hazards Earth Syst. Sci.

Discussion started: 12 February 2018

(c) Author(s) 2018. CC BY 4.0 License.

Natural Hazards

and Earth System

Sciences

Discussions

Note: This work has been produced from the graduate thesis named "Tarihi Yığma Bir Binanın Deprem Güvenlik Analizi:Tarihi Konya-Gazi Lisesi(Darü’l Muallim) Örneği’” under the guidance of M. Sami Döndüren.

6. References

Akgündüz N.: Deprem Bölgelerinde Yığma Yapı Tasarımının Yönetmeliğe Göre İncelenmesi. İstanbul Teknik Üniversitesi. Fen Bilimleri Enstitüsü., 2004.

Aköz A. H.: Deprem Etkisi Altındaki Tarihi Yığma Yapıların Onarım Ve Güçlendirilmesi. Fen Bilimleri Enstitüsü. İstanbul Teknik Üniversitesi., 2008.

Anonim.: Boğaziçi Üniversitesi Kandilli Rasathanesive Deprem Araştırma Enstitüsü., 2016.

Anonim.: Milli Eğitim Bakanlı̆̆ Resmi web sitesi. Erişim., 2016.

http://konyalisesi.meb.k12.tr/meb iys dosyalar/42/26/964123/fotograf galerisi 505807.html?CHK=c901f a767b2bf8fd09fe9c1da1d6e4c1.

Anonim.: Mimar Muzaffer'in Konya Öğretmen Lisesi. Orta Doğu Teknik Üniversitesi Mimarlık Fakültesi Dergisi. 4 (1)., 2016.

Artar M.: Structural identification of the Sehzade Mehmet Mosque through static and dynamic analyses . MSc. Thesis. Boğazici University. İstanbul., 2006.

Atabey İ.: Yığma Binaların Performans Analizi Sivas Suşehri Aşağısarıca İlköğretim Okulu Örneği. Gazi Üniversitesi Fen Bilimleri Enstitüsü Yapı Eğitimi. Ankara., 2011.

Ateş İ. S.: Mevcut binaların depreme karşı performans analizi için kullanılan alternatif yöntem ve paket programların karşılaştırılması. Çukurova Üniversitesi Fen Bilimleri Enstitüsü., 2010.

Aytekin İ.: Donatısız ve Sarılmış Yı̆̆ma Yapıların Deprem Davranışlarının İncelenmesi. Yüksek Lisans Tezi. Sakarya Üniversitesi Fen Bilimleri Enstitüsü. Sakarya., 2006.

Bayülke N.: Yığma yapıların deprem davranışı ve güvenliği. 1. Türkiye Deprem Mühendisliği ve Sismoloji Konferans1. Ankara., 2011.

Çaktı E., Saygılı Ö., Görk S., Zengin E., Oliveira C. S., Lemos J. V.: Edirnekapı Mihrimah Sultan Camii Minaresinin Deprem Davranışı. Vakıf Restorasyon Yıllığı Sayı: 6. İstanbul., 2013.

Çiftçi Ç.: Bir kentsel donatım olarak Tarihi Konya Gazi Lisesi (Darü’l Muallimin'den Günümüze). Aybil Yaymları., 2011.

Dabanlı Ö.: Tarihi yı̆̆ma yapıların deprem performansının belirlenmesi. Fen Bilimleri Enstitüsü., 2008.

DBYBHY.: Afet İşleri Genel Müdürlüğü. Deprem Araştırma Dairesi. Ankara., 2007.

Uguz S.: Tarihi Yığma Bir Binanın Deprem Güvenlik Analizi:Tarihi Konya-Gazi Lisesi(Darü’l Muallim) Örneği”. Selçuk Üniversitesi. Fen Bilimleri Enstitüsü. Konya., 2016.

Jeen H. W.: A Study of Earthquake Recurrence based on a One-body Spring-slider Model in the Presence of Thermal-pressurized Slip-weakening Friction and Viscosity. https://doi.org/10.5194/nhess-2017-459.

Stephanie L.: Earthquakes on the surface: earthquake location and area based on more than 14500 ShakeMaps. https://doi.org/10.5194/nhess-2017-422. 